\title{
Efficiency of banks and human resources
}

\author{
Valentas Gružauskas \\ Kaunas University of Technology, \\ Lithuania \\ valentas.gruzauskas@ktu.edu \\ Eva Grmanová \\ Alexander Dubrèk University of Trenčin, \\ Slovakia \\ eva.grmanova@tnuni.sk
}

\begin{abstract}
This paper focuses on efficiency of banks and human resources. The subjects of our analysis are banks based in Slovakia. The aim of this paper is to determine the relationship between technical efficiency on one side and the number of banks' employees and personnel expenses/number of employees on the other side. Technical efficiency scores were determined using DEA models. DEA models are quantitative models used to express the relative efficiency score. They are based on linear programming transforming multiple inputs into multiple outputs. Banks can be divided into groups according to their number of employees. Medium-sized banks reached higher arithmetic average of the efficiency scores than large banks. Banks with above-average personnel expenses/ number of employees reached higher arithmetic average of the efficiency scores than thebanks with below-average personnel expenses/ number of employees. Based on the Tobit regression, especially interesting is the positive effect personnel expenses/ number of employees have on the efficiency score.
\end{abstract}

Keywords: Data Envelopment Analysis (DEA), efficiency score, commercial banks, Slovakia

JEL Classification: G21, C61

\section{INTRODUCTION}

In every country, banking system plays an important role within national economy. Its positive development has an impact on economic growth of the state. asic elements of the banking system are commercial banks. Increasing their performance and efficiency can positively affect the development of the entire system. 
International research monitors the relationship between bank's efficiency and various other factors that are grouped as the so-called environmental factors. These are the factors that are not under the influence of management. The size of a bank can be also considered environmental factor. It can be expressed by various indicators.

\section{Research Goal}

The subject of our analysis is the efficiency of banks based in Slovakia in 2015. The list of banks is in Table 1. The NBS (2015) classifies three building societies and Slovenská záručná a rozvojová banka, a.s., which is a specialised financial institution aimed at supporting small and medium-sized enterprises, as banks. The efficiency of banks in regard to human resources will be observed. Human resources of the banks will be compared based on their size and personnel costs. Data were drawn from annual reports of banks (2015) and from the database Finstat (2015).

The aim of this paper is to contribute to the knowledge of the efficiency of banks in the Slovak Republic in the context of the number of their employees and personal expenses.

We will deal the following research question: Do the number of employees and personnel expenses/number of employees affect the efficiency of banks?

There are several approaches to evaluating efficiency of the subjects analysed. In our analysis, efficiency is characterized by the technical efficiency score calculated using Data Envelopment Analysis models (DEA). We used the radial input-oriented BCC model. Tobit model was used to analyse relations between the indicators.

This paper has the following structure: methodology is described in the following section. It is followed by the literature review. The next section describes the empirical results and discussion; the last section is the conclusion.

\section{LITERATURE REVIEW}

The commercial bank is a specialised enterprise which, seeking financial gain, carries out bank transactions. It collects financial means, which are consequently placed through loans, conveys payment transactions, and provides services, trades with money on the capital market. Commercial banks have an important role in the process of GDP creation and redistribution. They are the key element of the financial system (Belás et al., 2015; Nuhiu et al., 2017). A well developing financial system is an important attribute of the development of the national economy as a whole.

Since the human is the main production capital and the creator of corporate value, its position and role vary (Kot \& Pigoń, 2014; Krajňáková \& Vojtovič, 2012; Petrenko \& Psiuk, 2018; Popov, 2018). The personnel represent a crucial element of the business policy of commercial banks. Its level greatly influences the quality of products and services, the satisfaction of clients and thus the overall performance of the commercial bank (Belás et al., 2015; Luhn et al., 2017; Warter \& Warter, 2015). The bank's operations and performance are to a great extent dependent on the quality, organisation, management and other attributes of the bank's personnel. Some characteristics of Slovak banks can be generalised. Ferenčák (2016) claims that according to Kunerta, the general director of UniCredit Bank, some differences between the personnel of Slovak and Czech banks can be noticed easily. Czech personnel are more disciplined and oriented on goals in the structure. Slovak personnel, on the other hand, are more empathic and communicative. It follows from the surveys of Belás et al. (2015) that some factors related to the banks' employees might greatly influence the actions and results of banks that are connected to clients or to the position of the commercial bank on the national banking market. Surveys show that a high level of the banks employees' dissatisfaction generates low acceptance of the clients' needs (Lazányi, 2017). 
There are a relatively large number of publications that deal with the research of the efficiency of banks. Authors apply various methods to calculate efficiency. When applying DEA models, the estimated efficiency score is influenced by the inputs and outputs used. Three main approaches have been published in regard to the selection of inputs and outputs used to express the efficiency of banks. The first was Benston (1965) who published an approach known as the production approach. The production approach considers deposits to be the outputs. This approach is used very often. Sherman \& Gold (1985) used this approach to evaluate the efficiency of banks. The bank is primarily perceived as a producer of deposit and loan accounts. Inputs are indicators of labour and capital. On the output side there is the number of accounts and their financial value. Sealeay \& Lindley (1977) published an approach known as the intermediation approach. The bank is primarily considered as the provider of funds from depositors that are then provided to debtors. The third approach is the value-added approach. Only the categories that contribute to a substantial value added are treated as outputs whilst the others are treated as inputs or intermediate products (Bod'a \& Zimková, 2015).

Several studies have focused on the research of the efficiency of banks in the Slovak Republic. Košak \& Zajc (2009) examined the efficiency of banks in five EU member countries from Central and Eastern European countries - the Czech Republic, Hungary, Poland, Slovakia, Slovenia, and three Baltic countries - Estonia, Lithuania and Latvia. The highest average efficiency score was achieved by banks in Slovakia, followed by banks in Poland. The lowest average efficiency scores had banks in the Czech Republic (Košak \& Zajc, 2009). Bod’a \& Zimková (2015) analysed the results of the efficiency of 11 banks in the Slovak Republic and compared three approaches to assessing efficiency - intermediation approach, service-oriented approach and profit-oriented approach. The non-parametric method of evaluation is used based on the slack-based measure model of the Data Envelopment Analysis. The result was that general impressions of the efficiency status of individual banks as obtained within the three approaches were similar in most cases.

Some scientific studies focus on analyzing the efficiency of Slovak banks in the context of their size. Andries (2011) compared the technical efficiency of Slovak banks to the banks of Bulgaria, the Czech Republic, Poland, Romania, Slovenia and Hungary in the years 2004-2008. Banks were classified into 3 different categories based on the size of their total assets: The results reveal that medium-sized banks experience the highest growth in terms of productivity and small banks are more efficient than large and medium-sized banks (Andries, 2011; Andrei, et al., 2016). Stavárek \& Šulganová (2009) estimated the efficiency of 13 Slovak commercial banks in the period 2001-2005. They applied the parametric Stochastic Frontier Approach and Cobb-Douglas production function. The authors concluded that 11 banks recorded an increase in efficiency. Slovak banks had a greater ability to use inputs in the production process. The authors assessed differences in the average efficiency score of small, medium-sized and large banks. Banks were divided into groups according to their total assets. The highest average efficiency had medium-sized banks - almost $84 \%$. Small and large banks had an average efficiency of approximately $75 \%$ for the whole period.

\section{METHODOLOGY}

\subsection{DEA Models}

DEA models were designed as specialised modelling tools for assessing efficiency. DEA models use linear programming. They transform multiple inputs into multiple outputs and construct nonparametric data envelopments (Yang, 2017). The subjects analysed are called Decision Making Units - DMUs. Providing there are variable returns to scale, data envelopment is convex. DMUs that are part of the convex data envelopment are called technically efficient (or just efficient). Efficiency of all DMUs is assessed relative 
to this envelopment and is expressed by the efficiency score. Efficient DMUs have an efficiency score equal to one. Non-efficient DMUs have an efficiency score other than one. In our analysis, we used the radial input-oriented BCC model.

We assume that we have $\mathrm{n}$ homogeneous DMUs, for which we monitor $r$ outputs and $m$ inputs. The matrix of inputs will be marked $\mathbf{X}=\left[x_{j k}, j=1, \ldots, m, k=1, \ldots, n\right]$, the matrix of outputs will be marked $\mathbf{Y}=\left[y_{i k}, i=1, \ldots, r, \quad k=1, \ldots, n\right]$.

The efficiency score $\theta_{q}$ in the input-oriented BCC model is expressed in the matrix form $\min$ $z=\theta_{q}-\varepsilon\left(\mathbf{e}^{T} \mathbf{s}^{*}+\mathbf{e}^{T} \mathbf{s}^{-}\right)$,

under the conditions

$$
\begin{gathered}
\mathbf{X} \lambda+\mathbf{s}^{-}=\theta_{q} \mathbf{x}_{q}, \\
\mathbf{Y} \lambda-\mathbf{s}^{+}=\mathbf{y}_{q}, \\
\mathbf{e}^{T} \lambda=1, \\
\lambda, \mathbf{s}^{+}, \mathbf{s}^{-} \geq 0,
\end{gathered}
$$

where ${ }^{\theta_{q}}$ expresses the efficiency score of the DMU $U_{q}$,

$\mathbf{X}$ is the matrix of inputs,

$\mathbf{Y}$ is the matrix of outputs,

$\mathbf{s}^{+}, \mathbf{s}^{-}$are deviational variables, $\boldsymbol{\lambda}$ is the matrix of weights,

$\mathbf{e}^{T}=(1,1 . ., 1)$,

$\varepsilon$ is the infinitesimal constant (Jablonský \& Dlouhý, 2004).

Our paper is based on the Pareto-Koopmans definition of efficiency. DMU is considered efficient if the efficiency score is 1 and all deviational variables are equal to 0.

\subsection{Tobit Model}

Regression analysis is a statistical method for estimating the relationships among variables. Several techniques for carrying out regression have been developed. In our case technical efficiency $\theta_{q}$ is a dependent variable in regression. The efficiency score of the DMU has a value in the range $\langle 0,1\rangle$. It is therefore a limited dependent variable. Consequently, we will use the Tobit regression - Censored Regression Model (or only Tobit model) (Grmanová \& Pukala, 2018). The standard Tobit model can be defined as follows for observation

$$
y_{i}^{*}=\beta^{T} x_{i}+\varepsilon_{i}, \quad y_{i}=y_{i}^{*} \text {, if } y_{i}^{*} \geq 0 \text { and } y_{i}=0 \text {, otherwise }
$$

$\varepsilon_{i} \sim N\left(0, \sigma^{2}\right)$

$x_{i}$ and $\beta$ are vectors of explanatory variables and unknown parameters,

$y_{i}^{*}$ is a latent variable,

$y_{i}$ is efficiency score (Güneş \& Yilmaz, 2016).

\section{EMPIRICAL RESULTS AND DISCUSSION}

\section{Number of employees and personal expenses}


Banks based in the Slovak Republic differ significantly in the number of employees. Slovenská sporitel'ňa, a.s. has the highest number of employees. In the long term, it has had more than 4000 employees. ČSOB stavebná sporitel’ňa, a.s. has the lowest number of employees. Banks can be divided into groups according to the number of employees. Medium-sized banks are the ones with the number of employees up to 250. Large banks have a number of employees higher than 250. Among the 13 banks observed, three were medium-sized banks, i.e., approximately $23.1 \%$. The rest of the banks belonged to the group of large banks. The number of employees and the groups of banks are in Table 1.

Table 1

Number of employees (31.12.2015)

\begin{tabular}{|l|c|c|c|}
\hline & $\begin{array}{c}\text { Number of } \\
\text { employees }\end{array}$ & $\begin{array}{c}\text { Groups of } \\
\text { banks }\end{array}$ & $\begin{array}{c}\text { Personnel expenses/ number } \\
\text { of employees (thous. EUR) }\end{array}$ \\
\hline Československá obchodná banka, a.s. & 2136 & large & 30.52 \\
\hline ČSOB stavebná sporitel’na, a.s. & 114 & medium & 24.67 \\
\hline OTP banka Slovensko, a.s. & 669 & large & 26.14 \\
\hline Poštová banka, a.s. & 836 & large & 34.08 \\
\hline Prima banka Slovensko, a.s. & 692 & large & 24.52 \\
\hline Privatbanka, a.s. & 166 & medium & 38.10 \\
\hline Prvá stavebná sporitel’ňa, a.s. & 412 & large & 40.63 \\
\hline Sberbank Slovensko, a.s. & 658 & large & 34.71 \\
\hline Slovenská sporitel'ňa, a.s. & 4205 & large & 30.63 \\
\hline Slovenská záručná a rozvojová banka, a.s. & 167 & medium & 40.34 \\
\hline Tatra banka, a.s. & 3571 & large & 29.10 \\
\hline Všeobecná úverová banka, a.s. & 3987 & large & 25.58 \\
\hline Wüstenrot stavebná sporitel’na, a. s. & 263 & large & 13.33 \\
\hline
\end{tabular}

Source: Annual bank reports (2015), Finstat (2015)

In the next step we analysed operating costs/number of employees and personnel costs/number of employees. The highest operating costs/ largest number of employees had Poštová banka, a.s. The lowest operating costs/ smallest number of employees had Wüstenrot stavebná sporitel'ňa, a.s. The average value of the indicator operating costs/number of employees was higher for large banks than for middle-sized banks.

Personnel costs are part of the operating costs. Banks make a significant effort to optimize their personnel costs. Most managers are aware of the importance of cost reduction as well as personnel motivation by adequate financial evaluation. The approach of Slovak banks is significantly different. Prvá stavebná sporitel’ňa, a.s. and Slovenská záručná a rozvojová banka, a.s. have the highest personnel costs attributed to one employee. The values of this indicator for the three largest Slovak banks on the banking market are similar to or lower than the average. Slovenská sporitel'ňa, a.s. and Tatra banka, a.s. have values that are close to the average. Všeobecná úverová banka, a.s. has a value of the indicator lower than the average. Wüstenrot stavebná sporitel’ňa, a.s. has the lowest personnel costs per employee. Medium-sized banks have higher average personnel expenses/number of employees than large banks. However, it should 
be noted that the indicator personnel expenses/number of employees reflects the average costs per employee in the bank. However, employees in the bank work on different positions. Thus, the indicator can be significantly affected by extremely high salaries of top management. Descriptive statistics of operating costs/number of employees and personnel expenses/number of employees are in Table 2.

Table 2

Descriptive statistics of indicators

\begin{tabular}{|l|c|c|c|c|c|c|}
\hline & & $\begin{array}{c}\text { Arithmetic } \\
\text { average } \\
\text { (thous. Eur) }\end{array}$ & $\begin{array}{c}\text { Median } \\
\text { (thous. Eur) }\end{array}$ & $\begin{array}{c}\text { Min } \\
\text { (thous. Eur) }\end{array}$ & $\begin{array}{c}\text { Max } \\
\text { (thous. Eur) }\end{array}$ & $\begin{array}{c}\text { Standard } \\
\text { deviation }\end{array}$ \\
\hline $\begin{array}{l}\text { Operating } \\
\text { costs/ } \\
\text { number of } \\
\text { employees }\end{array}$ & All banks & 60.912 & 62.037 & 30.346 & 85.810 & 13.097 \\
\cline { 2 - 7 } & $\begin{array}{c}\text { Large } \\
\text { Pedium }\end{array}$ & 61.045 & 61.347 & 30.346 & 85.810 & 13.786 \\
Personnel & All banks & 30.181 & 30.520 & 13.330 & 40.630 & 7.617 \\
\cline { 2 - 7 } $\begin{array}{l}\text { number of } \\
\text { employees }\end{array}$ & Large & 28.924 & 29.810 & 13.330 & 40.630 & 7.334 \\
& Medium & 34.370 & 38.100 & 24.670 & 40.340 & 8.475 \\
\hline
\end{tabular}

Source: own processing in Statistica

\section{Efficiency scores of banks}

The intermediation approach was used to evaluate the efficiency of banks. Our analysis was based on the selection of inputs and outputs according to Stavárek \& Šulganová (2009). We reduced the number of inputs and the number of outputs to 2 due to a small number of analysed banks. Efficiency scores were evaluated based on the indicators: inputs - liabilities to banks and clients and operating costs, and outputs loans to banks and clients and non-interest income. Data were drawn from the annual reports of banks in the year 2015 and Finstat (2015). Descriptive statistics of inputs and outputs are in the Table 3.

Table 3

Descriptive statistics of inputs and outputs

\begin{tabular}{|l|c|c|c|c|c|}
\hline Indicators (thous. Eur) & $\begin{array}{c}\text { Arithmetic } \\
\text { average }\end{array}$ & Median & Min & Max & Standard deviation \\
\hline Loans to banks and clients & 3209246 & 1712448 & 171726.0 & 9536299 & 3547407 \\
\hline Non-interest income & 47341 & 16706 & 1992.0 & 153066 & 56819 \\
\hline Liabilities to banks and clients & 3536256 & 1732199 & 223758.0 & 11062984 & 3795143 \\
\hline Operating costs & 86352 & 41974 & 5196.0 & 260866 & 95310 \\
\hline
\end{tabular}

Source: own processing in Statistica

All the indicators have a significantly higher arithmetic average than the median. Slovenská sporitelnna, a.s. reached the maximum value of all the indicators analysed except for non-interest income. The maximum value of non-interest income had Tatra banka, a.s. ČSOB stavebná sporitelňa, a.s. had the lowest value of liabilities to banks and clients and operating costs. OTP banka Slovensko, a.s. had the lowest value of loans to banks and clients. The lowest value of non-interest income had Slovenská záručná a rozvojová banka, a.s.

In the next step, we calculated the technical efficiency score in the input-oriented BCC model. Descriptive statistics of efficiency scores are in Table 4. The arithmetic average of the efficiency scores was 
equal to $87.24 \%$. 6 banks were efficient, which is $46.15 \%$ of the number of banks. Efficient were the banks: ČSOB stavebná sporitel’ňa, a.s., Privatbanka, a.s., Prvá stavebná sporitel'ňa, a.s., Slovenská sporitelňna, a.s., Slovenská záručná a rozvojová banka, a.s. and Tatra banka, a.s. Among these banks were three mediumsized banks and three large banks efficient. I.e., all three medium-sized banks were efficient. 30\% of large banks were efficient. Medium-sized banks reached a higher arithmetic average of the efficiency scores than large banks.

Table 4

Descriptive statistics of efficiency scores (2015)

\begin{tabular}{|l|c|c|c|c|c|}
\hline & $\begin{array}{c}\text { Arithmetic } \\
\text { average }\end{array}$ & Median & Min & Max & Standard deviation \\
\hline $\begin{array}{l}\text { Efficiency scores - } \\
\text { all banks }\end{array}$ & 0.8724 & 0.9865 & 0.5541 & 1.0000 & 0.1659 \\
\hline $\begin{array}{l}\text { Efficiency scores - } \\
\text { medium-sized banks }\end{array}$ & 1.0000 & 1.0000 & 1.0000 & 1.0000 & 0 \\
\hline $\begin{array}{l}\text { Efficiency scores - } \\
\text { large banks }\end{array}$ & 0.8342 & 0.8431 & 0.5541 & 1.0000 & 0.1722 \\
\hline
\end{tabular}

Source: own processing in Statistica

Banks with above-average personnel expenses/ number of employees reached a higher arithmetic average of the efficiency scores than banks with below-average personnel expenses/ number of employees. Among the banks that had above-average personnel expenses/ number of employees, four banks were efficient, i.e., 57.14\%. Among the banks that had below-average personnel expenses/ number of employees, two banks were efficient, i.e., 33.33\%. Thus, in 2015 banks with above-average personnel expenses/ number of employees were on average more efficient than banks with below-average personnel expenses/ number of employees. Descriptive statistics of efficiency scores are in Table 5.

Table 5

Descriptive statistics of efficiency scores (2015)

\begin{tabular}{|l|c|c|c|c|c|}
\hline & $\begin{array}{c}\text { Arithmeti } \\
\text { c average }\end{array}$ & Median & Min & Max & $\begin{array}{c}\text { Standard } \\
\text { deviation }\end{array}$ \\
\hline Efficiency scores -all banks & 0.8724 & 0.9865 & 0.5541 & 1.0000 & 0.1659 \\
\hline $\begin{array}{l}\text { Efficiency scores - banks with below average of } \\
\text { personnel expenses/ number of employees }\end{array}$ & 0.8260 & 0.8431 & 0.5541 & 1.0000 & 0.1894 \\
\hline $\begin{array}{l}\text { Efficiency scores -banks with above average of } \\
\text { personnel expenses/ number of employees }\end{array}$ & 0.9123 & 1.0000 & 0.6884 & 1.0000 & 0.1454 \\
\hline
\end{tabular}

Source: own processing in Statistica

Using the Tobit model, we analysed in the Matrixer software the relationship between the dependent variable - the score of technical efficiency and the independent variables - personnel expenses/ number of employees (PE) and number of employees (NE).

Thus, that the following relationship applies to the $\mathrm{j}^{\text {th }}$ bank $\theta_{j}=\beta_{1} P E_{j i}+\beta_{2} N E+\varepsilon_{j} \varepsilon_{i} \sim N\left(0, \sigma^{2}\right)$. 
Parameters of Tobit model with dependent variable BCC score

\begin{tabular}{|l|l|}
\hline \multicolumn{2}{|c|}{ Coefficient of determination: $56.03 \%$} \\
\hline$\beta_{1}$ & 0.02557 \\
\hline$\beta_{2}$ & 0.00006 \\
\hline
\end{tabular}

Source: own processing in Matrixer

The coefficient of determination (Table 6) is 56.03\%. The parameters of Tobit regression are positive. Parameter $\beta_{2}$ is a very small number. Especially interesting is the positive effect personnel expenses/ number of employees on the bank's efficiency. Banks that are trying to achieve low personnel expenses may ultimately reduce their efficiency as well. These results are in line with the theory of human resource management. Every enterprise is formed by people and the basic condition of each organization's success is to realize the value and importance of people in the work process (Antošová, 2008). Low personnel expenses will have only a short-term effect for banks.

\section{CONCLUSION}

The aim of this paper was to evaluate the technical efficiency of banks using the models of Data Envelopment Analysis in order to analyse the impact of the number of employees and personnel expenses/number of employees.

Banks varied considerably in the number of employees and personnel expenses/number of employees. $46.15 \%$ of the number of banks were efficient. All medium-sized banks were efficient, i.e., medium-sized banks reached a higher arithmetic average of the efficiency scores than large banks. At the same time, reached banks with above-average personnel expenses / number of employees a higher arithmetic average of the efficiency scores than banks with below-average personnel expenses/ number of employees. Based on the Tobit regression, especially interesting is the positive effect personnel expenses/ number of employees on the efficiency score. Over the longer term, lower personnel expenses may lead to a decline in the bank's performance.

Our study had some limitations as well. The banking market in the Slovak Republic is relatively small. In our analysis, we focused on the findings determined during one year. To generalize this conclusion, however, it would be necessary to examine the efficiency over a longer period of time. Regarding the human resources and efficiency of banks, further research is necessary.

\section{REFERENCES}

Andrei, A., Galupa, A., Androniceanu A., \& Georgescu, I.A. (2016). Monetary Policy with Constant Real Stock of Bonds. Economic Computation and Economic Cybernetics Studies and Research, 50(3), 101-116.

Andries, A.M. (2011). The Determinants of Bank Efficiency and Productivity Growth in the Central and Eastern European Banking Systems. Eastern European Economics, 49(6), 39-59. doi: http://dx.doi.org/10.2753/EEE0012$\underline{8775490603 .}$

Antošová, M. (2008). Management of Human Resources in Practice. Faculty BERG, Košice.

Banks. (2015). Annual Reports of Banks 2015.

Belás, J. et al. (2015). Management's Financial Performance, Business and Risk in Commercial Bank. Žilina: GEORG

Benston, G.J. (1965). Branch Banking and Economies of Scale. The Journal of Finance, 20(2), $312-331$. doi: 10.1111/j.1540-6261.1965.tb00212.x

Bod'a, M., \& Zimková, E. (2015). Efficiency in the Slovak Banking Industry: a Comparison of Three Approaches. Prague Economic Papers, 24(4). doi: 10.18267/j.pep.546. 
Bhasin, M. (2016). Challenge of mitigating bank frauds by judicious mix of technology: Experience of a developing country. Economics, Management And Sustainability, 1(1), 23-41. doi: https://doi.org/10.14254/jems.2016.1-1.3.

Ferenčák, T. (2016). Boss of UniCredit Bank: Slovaks Are Completely Different Type of Employees as Czechs. Economics Newspaper, 7.01.2016

Finstat. (2015). Retrieved from www.finstat.com.

Grmanová, E., \& Pukala, R. (2018). Efficiency of insurance companies in the Czech Republic and Poland. Oeconomia Copernicana, 9(1), 71-85. doi: https://doi.org/10.24136/oc.2018.004.

Güneş, N., \& Yilmaz, A. (2016). Determinants of Efficiencies in Turkish Banking Sector. (Tobit Analysis). International Journal of Economics and Finance, 8(2), 215-225.

Jablonský, J., \& Dlouhý, M. (2004). Models for Evaluation of Production Units' Efficiency. Professional Publishing, Prague.

Košak, M., \& Zajc, P. (2009). Determinants of Bank Efficiency Differences in the New EU Member Countries. Baltic Journal of Economics, 9(2), 67-89.

Kot, S., \& Pigoń, Ł. (2014). Effective occupational counselling for the unemployed. Polish Journal of Management Studies, 10(1), 54-62.

Krajňáková, E., \& Vojtovič, S. (2017). Struggles of older workers at the labour market. Economics and Sociology, 10(1), 319-333.

Lazányi, K. (2017). Innovation - the role of trust. Serbian Journal of Management, 12(2), 331-344.

Luhn A., Aslanyan S., Leopoldseder C., \& Priess P. (2017). An evaluation of knowledge management system's components and its financial and non-financial implications. Entrepreneurship and Sustainability Issues, 5(2), 315-329. doi: https://doi.org/10.9770/jesi.2017.5.2(11).

NBS. (2015). Available at: www.nbs.sk.

Nuhiu, A., Hoti, A., \& Bektashi, M. (2017). Determinants of commercial banks profitability through analysis of financial performance indicators: evidence from Kosovo. Business: Theory and Practice, 18, 160-170.

Petrenko, V., \& Psiuk, R. (2018). Management of functionaries' development of the enterprise management system by application of the criteria experts assessment by method of functional reliability. Economics, Management and Sustainability, 3(1), 58-64. doi: https://dx.doi.org/10.14254/jems.2018.3-1.5.

Popov, E., \& Vlasov, M. (2018). Assessment of Intellectual Development of the Human Capital of Hi-Tech Productions. Montenegrin Journal of Economics, 14(1), 121-131.

Sealeay, C.W., \& Lindley, J.T. (1977). Inputs, Outputs, and a Theory of Production and Cost at Depository Financial Institutions. The Journal of Finance, 32(4), 1251-1266. doi: http://dx.doi.org/10.1111/j.1540-6261.1977.tb03324.x

Sherman, D.H., \& Gold, F. (1985). Bank Branch Operating Efficiency: Evaluation with Data Envelopment Analysis. Journal of Banking and Finance, 1985, 9(2), 297-315. doi: http://dx.doi.org/10.1016/0378-4266(85)90025-1

Stavárek, D., \& Šulganová, J. (2009). Analysis of Efficiency of Slovak Banks Using Stochastic Frontier Approach. Central European Review of Economic, 12(1), 27-33.

Warter, I., \& Warter, L. (2015). The new face of global M\&A. Intercultural issues in banking industry. Forum Scientiae Oeconomia, 3(1), 127-138).

Yang, C.-C. (2017). Reduction of non-performing loans in the banking industry: an application of data envelopment analysis. Journal of Business Economics and Management, 18(5), 833-851. doi: https://doi.org/10.3846/16111699.2017.1358209 